\title{
THE STRUCTURES OF KATANOSINS A AND B
}

\author{
Toshiyuki Kato, Hiroshi Hinoo, Yoshihiro Terui, \\ JUN'Ko KIKUCHI and JUN'ICHI SHOJI* \\ Shionogi Research Laboratories, Shionogi \& Co., Ltd., \\ Fukushima-ku, Osaka 553, Japan
}

(Received for publication December 8, 1987)

\begin{abstract}
${ }^{1} \mathrm{H}$ and ${ }^{13} \mathrm{C}$ NMR studies on katanosin A confirmed the presence of eight usual amino acid residues which were previously deduced by amino acid analysis and suggested the presence of $\beta$-hydroxyaspartic acid, $\beta$-hydroxyleucine and $\beta$-phenylserine residues. These amino acids were isolated and confirmed, including their stereochemistries, by comparison with the respective authentic specimens. Stereochemistries of the usual amino acids were determined by comparing the L-leucylated amino acids with reference compounds by HPLC. Lithium borohydride reduction and chromic acid oxidation of katanosin $\mathrm{A}$ and alkali-treated katanosin A elucidated a lactone linkage between the $C$-terminal Ser and phenylserine residues. Edman degradation on alkali-treated katanosin A clarified the total amino acid sequence. The difference in katanosins A and B was determined to be replacement of Val in A by Mle in B. Thus, the structures of katanosins $\mathrm{A}$ and $\mathrm{B}$ were elucidated.
\end{abstract}

Katanosins A (1) and $\mathbf{B}(\mathbf{2})$ are basic peptide antibiotics with molecular formulae of A: $\mathrm{C}_{57} \mathrm{H}_{95} \mathrm{~N}_{15} \mathrm{O}_{17}$ and $\mathrm{B}: \mathrm{C}_{58} \mathrm{H}_{97} \mathrm{~N}_{15} \mathrm{O}_{17}$. Amino acid analysis of the acid hydrolysate suggests that the amino acid constitution of 1 is Asp (1), Thr (1), Ser (1), Gly (1), Val (1), Leu (3), Arg (1) and three unusual amino acids (cited as U-1, U-2 and U-3 in the previous paper) and the difference between 1 and $\mathbf{2}$ is thought to be replacement of Val in $\mathbf{1}$ by Ile in $\mathbf{2}^{1 \text {. }}$.

The ${ }^{1} \mathrm{H}$ and ${ }^{13} \mathrm{C}$ NMR studies on $\mathbf{1}$ and $\mathbf{2}$, in which assignment of proton signals were made by ${ }^{1} \mathrm{H}-{ }^{1} \mathrm{H}$ correlation spectroscopy (COSY) spectra and spin decoupling experiments and assignment of carbon signals were made by CSCM and selective decoupling experiments (Table 1) clarified the presence of the above eight usual amino acid residues and furthermore suggested the presence of $\beta$-hydroxyaspartic acid, $\beta$-hydroxyleucine and $\beta$-phenylserine residues, which were considered to correspond to the three unusual amino acids (U-1, U-2 and U-3). The signals of quaternary carbons were assigned using ${ }^{1} \mathrm{H}-{ }^{13} \mathrm{C}$ long range coupling relations.

These unusual amino acids were isolated from the hydrolysates of a complex of $\mathbf{1}$ and $\mathbf{2}$ by preparative paper chromatography. The isolated amino acids were compared with the authentic specimens of L-threo- $\beta$-hydroxyaspartic acid, L-erythro- $\beta$-hydroxyaspartic acid, D,L-threo- $\beta$-hydroxyleucine, $\mathrm{D}, \mathrm{L}$-erythro- $\beta$-hydroxyleucine, $\mathrm{D}, \mathrm{L}-$ threo- $\beta$-phenylserine and $\mathrm{D}, \mathrm{L}$-erythro- $\beta$-phenylserine by ${ }^{1} \mathrm{H} \mathrm{NMR}$, and then measured for their CD spectra. Consequently, U-1 was identified with L-threo- $\beta$-hydroxyaspartic acid (HyAsp), U-2 with L-threo- $\beta$-hydroxyleucine (HyLeu) and U-3 with L-threo- $\beta$-phenylserine (PhSer), respectively.

L-threo- $\beta$-Hydroxyaspartic acid has already been isolated as an antibiotic substance and $\mathbf{L}$-threo$\beta$-hydroxyleucine has been isolated from a hydrolysate of an antibiotic ${ }^{2 \sim 4}$.

The stereochemistries of the usual amino acid residues were examined by the following method. The amino acid mixture by acid hydrolysis of the antibiotic was L-leucylated and compared by HPLC with respective reference compounds. As a result, D-allo-threonine (aThr), L-serine, L-valine, L- 
Table 1. ${ }^{1} \mathrm{H}$ and ${ }^{13} \mathrm{C}$ NMR data for katanosins $\mathrm{A}$ and $\mathrm{B}$ hydrochloride ${ }^{\mathrm{a}}$.

\begin{tabular}{|c|c|c|c|c|c|}
\hline \multirow{2}{*}{\multicolumn{2}{|c|}{ Assignment }} & \multicolumn{2}{|l|}{ A } & \multicolumn{2}{|l|}{ B } \\
\hline & & \multirow[t]{2}{*}{${ }^{1} \mathrm{H}^{b}$} & \multirow{2}{*}{$\frac{{ }^{13} \mathrm{C}^{\mathrm{c}}}{171.2(\mathrm{~s})}$} & \multirow[t]{2}{*}{${ }^{1} \mathrm{H}^{\mathrm{b}}$} & \multirow{2}{*}{$\frac{{ }^{13} \mathrm{C}^{\mathrm{c}}}{171.4(\mathrm{~s})}$} \\
\hline $\mathrm{Leu}^{1}$ & $\mathrm{CO}$ & & & & \\
\hline & $\mathrm{NH}_{3}^{+}$ & 8.32 br & & 8.28 br & \\
\hline & $\alpha-\mathrm{CH}$ & 4.13 br m & $51.3(\mathrm{~d})$ & 4.11 br $\mathrm{m}$ & $51.3(\mathrm{~d})$ \\
\hline & $\beta-\mathrm{CH}_{2}$ & $\sim 1.58 \mathrm{~m}$ & $40.0(\mathrm{t})$ & $\sim 1.57 \mathrm{~m}$ & $40.1(t)$ \\
\hline & & $\sim 1.53 \mathrm{~m}$ & & $\sim 1.53 \mathrm{~m}$ & \\
\hline & $\gamma-\mathrm{CH}$ & $\sim 1.62 \mathrm{~m}$ & $23.9(\mathrm{~d})$ & $\sim 1.61 \mathrm{~m}$ & $24.0(\mathrm{~d})$ \\
\hline & $\mathrm{CH}_{3}$ & $0.95 \mathrm{~d}(6.0)$ & $22.0(q)$ & $0.94 \mathrm{~d}(6.0)$ & $22.0(q)$ \\
\hline & $\mathrm{CH}_{3}$ & $0.91 \mathrm{~d}(6.0)$ & $22.3(q)$ & $0.89 \mathrm{~d}(6.0)$ & $22.3(\mathrm{q})$ \\
\hline \multirow[t]{8}{*}{ Leu $^{2}$} & $\mathrm{CO}$ & & $175.2(\mathrm{~s})$ & & $175.3(\mathrm{~s})$ \\
\hline & NH & $9.60 \mathrm{br}$ & & 9.57 br & \\
\hline & $\alpha-\mathrm{CH}$ & $3.78 \mathrm{br}$ & $55.2(\mathrm{~d})$ & 3.80 br & $55.3(\mathrm{~d})$ \\
\hline & $\beta-\mathrm{CH}_{2}$ & $1.85 \mathrm{~m}(\sim 12.8, \sim 3.0)$ & $39.3(t)$ & $1.86 \mathrm{~m}(\sim 13.2, \sim 3.3)$ & $39.4(t)$ \\
\hline & & $\begin{array}{c}1.33 \mathrm{~m}(\sim 2.3, \sim 11.4 \\
\sim 13.8)\end{array}$ & & $\begin{aligned} 1.33 \mathrm{~m}( & \sim 2.3, \sim 11.4 \\
& \sim 13.6)\end{aligned}$ & \\
\hline & $\gamma-\mathrm{CH}$ & $\sim 1.92 \mathrm{~m}$ & $23.5(\mathrm{~d})$ & $1.95 \mathrm{~m}$ & $23.6(\mathrm{~d})$ \\
\hline & $\mathrm{CH}_{3}$ & $0.92 \mathrm{~d}(6.4)$ & $23.1(q)$ & $0.93 \mathrm{~d}(6.4)$ & $23.1(\mathrm{q})$ \\
\hline & $\mathrm{CH}_{3}$ & $0.76 d(6.4)$ & $19.5(\mathrm{q})$ & $0.78 \mathrm{~d}(6.4)$ & $19.6(q)$ \\
\hline \multirow[t]{8}{*}{ PhSer } & $\mathrm{CO}$ & & $171.6(\mathrm{~s})$ & & $171.8(\mathrm{~s})$ \\
\hline & $\mathrm{NH}$ & $8.91 \mathrm{~d}(8.8)$ & & $8.93 \mathrm{~d}(8.5)$ & \\
\hline & $\alpha-\mathrm{CH}$ & $5.57 \mathrm{dd}(8.8,9.7)$ & $60.4(\mathrm{~d})$ & $5.56 \mathrm{dd}(8.5,10.0)$ & $60.4(\mathrm{~d})$ \\
\hline & $\beta-\mathrm{CH}$ & $6.84 \mathrm{~d}(9.7)$ & 74.1 (d) & $6.80 \mathrm{~d}(10.0)$ & 74.2 (d) \\
\hline & $\mathrm{Ph}-i$ & & $136.2(\mathrm{~s})$ & & $136.2(\mathrm{~s})$ \\
\hline & $\mathrm{Ph}-o$ & 7.41 d-like & $127.3(\mathrm{~d})$ & 7.40 d-like & $127.3(\mathrm{~d})$ \\
\hline & $\mathrm{Ph}-m$ & 7.23 t-like & $128.0(\mathrm{~d})$ & 7.23 t-like & $128.0(\mathrm{~d})$ \\
\hline & $\mathrm{Ph}-p$ & 7.19 t-like & $128.2(\mathrm{~d})$ & $7.18 \mathrm{t}$-like & $128.3(\mathrm{~d})$ \\
\hline \multirow[t]{8}{*}{ HyLeu } & $\mathrm{CO}$ & & $171.8(\mathrm{~s})$ & & $171.9(\mathrm{~s})$ \\
\hline & $\mathrm{NH}$ & $9.05 \mathrm{br}$ & & $9.05 \mathrm{br}$ & \\
\hline & $\alpha-\mathrm{CH}$ & $\sim 3.62 \mathrm{~m}$ & $59.5(\mathrm{~d})$ & $\sim 3.61 \mathrm{~m}$ & 59.5 (d) \\
\hline & $\beta-\mathrm{CH}$ & $3.43 \mathrm{~m}$ & $74.6(d)$ & $3.43 \mathrm{~m}$ & 74.7 (d) \\
\hline & $\beta-\mathrm{OH}$ & $5.35 \mathrm{br}$ & & 5.38 br & \\
\hline & $\gamma-\mathrm{CH}$ & $2.35 \mathrm{~m}$ & 29.9 (d) & $2.37 \mathrm{~m}$ & $30.0(\mathrm{~d})$ \\
\hline & $\mathrm{CH}_{3}$ & $0.98 \mathrm{~d}(6.4)$ & $19.3(\mathrm{q})$ & $0.99 \mathrm{~d}(6.4)$ & $19.3(q)$ \\
\hline & $\mathrm{CH}_{3}$ & $0.80 \mathrm{~d}(6.4)$ & $19.1(q)$ & $0.81 \mathrm{~d}(6.4)$ & $19.1(\mathrm{q})$ \\
\hline \multirow[t]{8}{*}{ Leu $^{5}$} & $\mathrm{CO}$ & & $172.2(\mathrm{~s})$ & & $172.8(\mathrm{~s})$ \\
\hline & $\mathrm{NH}$ & $7.12 \mathrm{~d}(6.4)$ & & $7.04 \mathrm{~d}(6.6)$ & \\
\hline & $\alpha-\mathrm{CH}$ & $4.06 \mathrm{~m}$ & $52.0(\mathrm{~d})$ & $4.09 \mathrm{~m}$ & 51.9 (d) \\
\hline & $\beta-\mathrm{CH}_{2}$ & $\sim 1.62 \mathrm{~m}$ & $40.9(t)$ & $\sim 1.59 \mathrm{~m}$ & $40.5(t)$ \\
\hline & & $\begin{array}{c}1.46 \mathrm{~m}(\sim 3.3, \sim 10.5 \\
\sim 13.8)\end{array}$ & & $\begin{aligned} 1.46 \mathrm{~m}( & \sim 2.5, \sim 10.8 \\
& \sim 12.3)\end{aligned}$ & \\
\hline & $\gamma-\mathrm{CH}$ & $\sim 1.92 \mathrm{~m}$ & $23.5(\mathrm{~d})$ & $1.92 \mathrm{~m}$ & $23.6(\mathrm{~d})$ \\
\hline & $\mathrm{CH}_{3}$ & $0.79 \mathrm{~d}(6.4)$ & $20.9(\mathrm{q})$ & $0.80 \mathrm{~d}(6.4)$ & $20.7(q)$ \\
\hline & $\mathrm{CH}_{3}$ & $0.75 \mathrm{~d}(6.4)$ & $23.1(q)$ & $0.75 \mathrm{~d}(6.4)$ & $23.4(q)$ \\
\hline \multirow[t]{9}{*}{ Arg } & $\mathrm{CO}$ & & $171.9(\mathrm{~s})$ & & $171.9(\mathrm{~s})$ \\
\hline & NH & $6.89 \mathrm{~d}(5.6)$ & & $6.93 \mathrm{~d}(5.5)$ & \\
\hline & $\alpha-\mathrm{CH}$ & 3.76 br m & $54.6(\mathrm{~d})$ & 3.72 br $\mathrm{m}$ & $54.8(\mathrm{~d})$ \\
\hline & $\beta-\mathrm{CH}_{2}$ & $\sim 1.50 \mathrm{~m}$ & $27.8(\mathrm{t})$ & $\sim 1.49 \mathrm{~m}$ & $27.6(t)$ \\
\hline & & $\sim 1.60 \mathrm{~m}$ & & $\sim 1.59 \mathrm{~m}$ & \\
\hline & $\gamma-\mathrm{CH}_{2}$ & $\sim 1.50 \mathrm{~m}$ & $26.0(t)$ & $\sim 1.49 \mathrm{~m}$ & $26.0(t)$ \\
\hline & & $\sim 1.23 \mathrm{~m}$ & & $\sim 1.24 \mathrm{~m}$ & \\
\hline & $\delta-\mathrm{CH}_{2}$ & 2.83 br m & $40.1(t)$ & 2.83 br m & $40.1(\mathrm{t})$ \\
\hline & $\delta$-NH & 7.27 br $t$ & & $\sim 7.26$ br $t$ & \\
\hline
\end{tabular}


Table 1. (Continued)

\begin{tabular}{|c|c|c|c|c|c|}
\hline \multirow{2}{*}{\multicolumn{2}{|c|}{ Assignment }} & \multicolumn{2}{|l|}{ A } & \multicolumn{2}{|l|}{ B } \\
\hline & & ${ }^{1} \mathrm{H}^{\mathrm{b}}$ & ${ }^{13} \mathrm{C}^{\mathrm{C}}$ & ${ }^{1} \mathrm{H}^{b}$ & ${ }^{13} \mathrm{C}^{\mathrm{C}}$ \\
\hline \multirow{7}{*}{ Val } & $\begin{array}{l}\mathrm{NH} \\
\| \\
\mathrm{C} \\
\vdots \\
\mathrm{NH}_{3}{ }^{+}\end{array}$ & 6.60 br s & $156.7(\mathrm{~s})$ & 6.60 br $s$ & $156.7(\mathrm{~s})$ \\
\hline & $\mathrm{CO}$ & & $170.7(\mathrm{~s})$ & & \\
\hline & $\mathrm{NH}$ & $7.50 \mathrm{~d}(9.0)$ & & & \\
\hline & $\alpha-\mathrm{CH}$ & $3.72 \mathrm{dd}(9.0,10.3)$ & 60.9 (d) & & \\
\hline & $\beta-\mathrm{CH}$ & $2.01 \mathrm{~m}$ & $29.2(\mathrm{~d})$ & & \\
\hline & $\mathrm{CH}_{3}$ & $0.92 \mathrm{~d}(6.4)$ & $19.0(q)$ & & \\
\hline & $\mathrm{CH}_{3}$ & $0.83 \mathrm{~d}(6.4)$ & $19.6(q)$ & & \\
\hline \multirow[t]{7}{*}{ Ile } & $\mathrm{CO}$ & & & & $171.0(\mathrm{~s})$ \\
\hline & NH & & & $7.51 \mathrm{~d}(11.0)$ & \\
\hline & $\alpha-\mathrm{CH}$ & & & $3.75 \mathrm{dd}(11.0,8.8)$ & $59.4(d)$ \\
\hline & $\beta-\mathrm{CH}$ & & & $\sim 1.80 \mathrm{~m}$ & 35.0 (d) \\
\hline & $\beta-\mathrm{CH}_{3}$ & & & $0.89 \mathrm{~d}(6.4)$ & $15.4(q)$ \\
\hline & $\gamma-\mathrm{CH}_{2}$ & & & $\begin{array}{l}\sim 1.05 \mathrm{~m} \\
\sim 1.51 \mathrm{~m}\end{array}$ & $25.7(t)$ \\
\hline & $\mathrm{CH}_{3}$ & & & $0.75+(6.5)$ & $10.1(\mathrm{q})$ \\
\hline \multirow[t]{6}{*}{ aThr } & $\mathrm{CO}$ & & $172.2(\mathrm{~s})$ & & $172.3(\mathrm{~s})$ \\
\hline & $\mathrm{NH}$ & $6.98 \mathrm{~d}(9.8)$ & & $7.01 \mathrm{~d}(9.7)$ & \\
\hline & $\alpha-\mathrm{CH}$ & $4.39 \mathrm{t}(9.8)$ & $57.0(\mathrm{~d})$ & $4.38+(9.7)$ & 57.1 (d) \\
\hline & $\beta-\mathrm{CH}$ & $3.56 \mathrm{~m}$ & $69.6(\mathrm{~d})$ & $\sim 3.95 \mathrm{~m}$ & $69.5(d)$ \\
\hline & $\beta-\mathrm{OH}$ & $5.23 d(5.6)$ & & $5.20 \mathrm{~d}(5.7)$ & \\
\hline & $\mathrm{CH}_{3}$ & $1.19 \mathrm{~d}(6.4)$ & $20.6(q)$ & $1.20 \mathrm{~d}(6.4)$ & $20.6(q)$ \\
\hline \multirow[t]{4}{*}{ Gly } & $\mathrm{CO}$ & & $168.3(\mathrm{~s})$ & & $168.4(\mathrm{~s})$ \\
\hline & NH & $9.07 \mathrm{t}(5.7)$ & & $9.06 t(6.0)$ & \\
\hline & $\alpha-\mathrm{CH}_{2}$ & 4.02 dd $(5.7,16.8)$ & $43.2(t)$ & $4.00 \mathrm{dd}(6.0,17.0)$ & $43.3(t)$ \\
\hline & & $3.54 \mathrm{dd}(5.7,16.8)$ & & $3.55 \mathrm{dd}(6.0,17.0)$ & \\
\hline \multicolumn{2}{|c|}{ HyAsn $\mathrm{CO}$} & & $168.9(\mathrm{~s})$ & & $169.0(\mathrm{~s})$ \\
\hline & NH & $7.54 \mathrm{~d}(10.0)$ & & $7.49 \mathrm{~d}(10.0)$ & \\
\hline \multirow{9}{*}{ Ser } & $\alpha-\mathrm{CH}$ & $4.76 \mathrm{dd}(10.0,2.0)$ & $55.4(\mathrm{~d})$ & $4.77 \mathrm{dd}(10.0,1.8)$ & $55.4(\mathrm{~d})$ \\
\hline & $\beta-\mathrm{CH}$ & $4.35 \mathrm{dd}(2.0,5.6)$ & $71.0(\mathrm{~d})$ & $4.36 \mathrm{dd}(1.8,5.7)$ & $70.9(\mathrm{~d})$ \\
\hline & $\beta-\mathrm{OH}$ & $5.50 \mathrm{~d}(5.6)$ & & $5.49 \mathrm{~d}(5.7)$ & \\
\hline & $\beta-\mathrm{CONH}_{2}$ & $7.14 \mathrm{br}$ & $173.0(\mathrm{~s})$ & 7.14 br & $173.2(\mathrm{~s})$ \\
\hline & $\mathrm{CO}$ & & $167.4(\mathrm{~s})$ & & $167.4(\mathrm{~s})$ \\
\hline & NH & $7.01 \mathrm{~d}(9.8)$ & & $6.99 \mathrm{~d}(\sim 9)$ & \\
\hline & $\alpha-\mathrm{CH}$ & $4.51 \mathrm{dt}(9.8,6.3)$ & $55.4(\mathrm{~d})$ & 4.51 dt $(9.3,6.5)$ & $55.3(\mathrm{~d})$ \\
\hline & $\beta-\mathrm{CH}_{2}$ & $\sim 3.62 \mathrm{~m}$ & $61.7(t)$ & $\sim 3.61 \mathrm{~m}$ & $61.7(t)$ \\
\hline & $\beta-\mathrm{OH}$ & $5.00 \mathrm{t}(6.2)$ & & $5.00 \mathrm{t}(6.4)$ & \\
\hline
\end{tabular}

a The data measured in DMSO- $d_{6}$ at $60^{\circ} \mathrm{C}$ were listed.

b $400 \mathrm{MHz} ; \delta$ in ppm relative to internal TMS, $J$ in $\mathrm{Hz}$.

- $100 \mathrm{MHz} ; \delta$ in ppm relative to internal TMS.

isoleucine and $\mathrm{D}$-arginine were confirmed and the three leucine residues were determined to be one D-form and two L-forms.

1 and 2 shows an IR absorption at $1745 \mathrm{~cm}^{-11}$, which is indicative of a lactone linkage. By treatment with dilute alkaline solution, $\mathbf{1}$ and $\mathbf{2}$ converted to biologically inactive products (alkalitreated katanosins A (3) and B (4)) in which the above IR absorption was absent (Fig. 1).

When 1 and 3 were reduced with lithium borohydride and the reduced products were hydrolyzed and analyzed for their amino acids, the relative content of Ser in 1 was extremely reduced, whereas 
Fig. 1. IR spectrum of alkali-treated katanosin $A(3)(\mathrm{KBr})$.

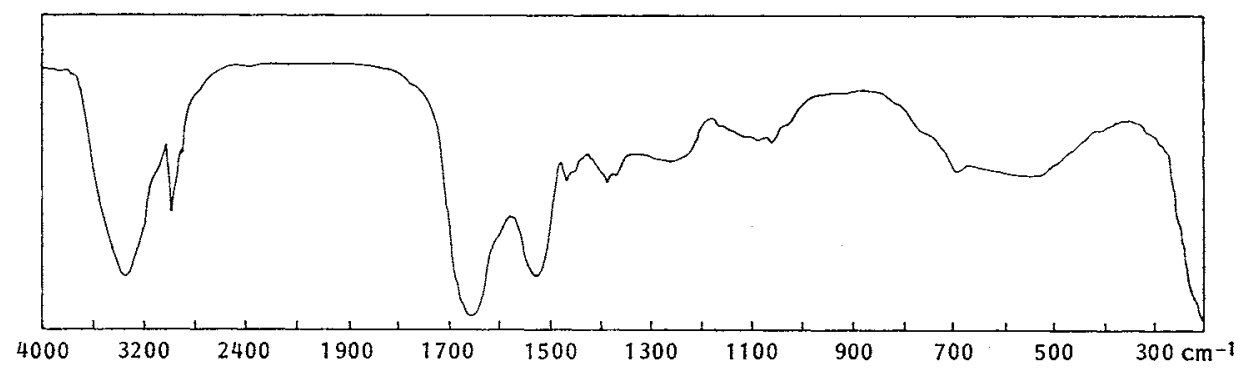

Fig. 2. Structures of katanosins A (1) and B (2).

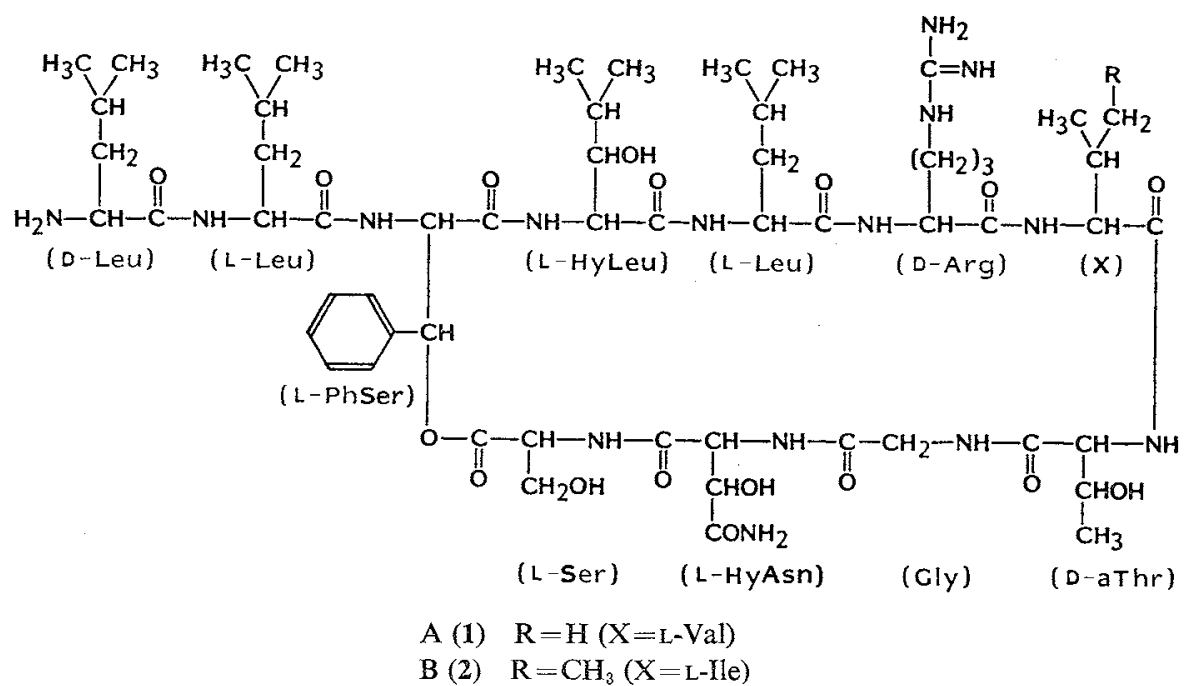

no change occurred in 3 by the reduction procedure. This meant that the carboxyl group of the Ser residue was involved in a lactone linkage in 1.

When 1 and 3 were oxidized with chromic acid and the products were hydrolyzed for amino acid analysis, HyAsp, aThr, Ser and HyLeu were reduced in 1, whereas in addition to the above hydroxyamino acids, PhSer was reduced in 3. This meant that the hydroxy group of the PhSer residue was involved in the lactone linkage. In the ${ }^{1} \mathrm{H}$ NMR of 1 , no proton signal assignable to the hydroxy group of the PhSer residue was observed, and the $\beta-\mathrm{CH}$ of the PhSer exhibited a very low field $\delta$ value (6.84).

Edman degradation of $\mathbf{3}$ successfully proceeded to the $C$-terminus, showing the amino acid sequence as below.

$\mathrm{Leu}^{1}-\mathrm{Leu}^{2}-\mathrm{PhSer}^{3}-\mathrm{HyLeu}^{4}-\mathrm{Leu}^{5}-\mathrm{Arg}^{6}-\mathrm{Val}^{7}-\mathrm{aThr}^{8}-\mathrm{Gly}^{9}-\mathrm{HyAsp}^{10}-\mathrm{Ser}^{11}$

The three Leu residues of 1 were one D-form and two L-forms as already mentioned. When the remaining peptide of the 1st step of the Edman degradation was hydrolyzed and the stereochemistry of the Leu in the hydrolysate was examined by the above described method, only L-form was detected. Thus, it was clarified that the Leu ${ }^{1}$ was D-form and the Leu ${ }^{2}$ and $\mathrm{Leu}^{5}$ were $\mathrm{L}$-forms. 
From the molecular formula of $\mathbf{1}$ and $\mathbf{2}$ which were established by elemental analysis and secondary ion (SI)-MS and the fact that the antibiotics show only basicity, it is evident that the HyAsp found in the hydrolysate is actually present as a $\beta$-hydroxyasparagine residue (HyAsn) in the intact antibiotics.

From the above, the structures of $\mathbf{1}$ and $\mathbf{2}$ were deduced as shown in Fig. 2.

The selective decoupling experiments clarified a lot of ${ }^{1} \mathrm{H}^{-13} \mathrm{C}$ long range coupling relations and supported the proposed amino acid sequence. The couplings found between the carbonyl carbons and the neighboring amide protons were especially useful to confirm the sequence.

\section{Experimental}

${ }^{1} \mathrm{H}$ and ${ }^{13} \mathrm{C}$ NMR spectra were measured with a Varian XL-400 spectrometer. CD curves were recorded with a Jasco J-40C automatic recording spectropolarimeter. Amino acid analysis was carried out with a Hitachi amino acid autoanalyzer 835 .

\section{Identification of the Unusual Amino Acid Residues}

Some $130 \mathrm{mg}$ of a complex of 1 and 2 were hydrolyzed with constant boiling $\mathrm{HCl}$ at $110^{\circ} \mathrm{C}$ for 5 hours. The hydrolysate, after concentration to dryness, was applied to preparative paper chromatography on a paper (Toyo Roshi No. 51) with BuOH - AcOH - water (4:1:2). A ninhidrinpositive zone of $\operatorname{Rf} c a .0 .2$ which contained Arg and U-1 and a zone of Rf $c a .0 .55$ which contained U-2, U-3 and Val, were extracted with $50 \% \mathrm{MeOH}$.

When the extract from the zone of $\mathrm{Rf} c a .0 .20$ was adsorbed on a Dowex $50 \mathrm{X} 8\left(\mathrm{H}^{+}\right)$column and eluted with $0.3 \mathrm{~N} \mathrm{NH}_{4} \mathrm{OH}, \mathrm{U}-1$ was eluted faster than Arg. The fraction of U-1 was concentrated to dryness, giving a colorless powder $(9.6 \mathrm{mg})$.

When the extract from the zone of Rf $c a .0 .55$ was applied to a MCI gel CHP-20P column (Mitsubishi Chemical Industries Limited) and eluted with water, U-2 and Val were eluted faster than U-3. The mixture of U-2 and Val were separated by paper chromatography on a paper (Toyo Roshi No. 51) with tert-BuOH - methyl ethyl ketone - conc ammoniacal water - water $(4: 3: 1: 2)$. The zone of U-2 ( Rf ca. 0.80 ) was extracted with $50 \% \mathrm{MeOH}, \mathrm{pH} 2.0$, the extract was adsorbed on a Dowex $50\left(\mathrm{H}^{+}\right)$ column, eluted with $0.3 \mathrm{~N} \mathrm{NH}_{4} \mathrm{OH}$, and the eluate was concentrated to give a colorless powder $(8.5$ $\mathrm{mg})$. The fraction of $\mathrm{U}-3$ gave a colorless powder $(1.9 \mathrm{mg})$ by concentration to dryness.

These samples of $U-1, U-2$ and U-3 were compared with respective authentic specimens. U-1 was compared with L-threo- $\beta$-hydroxyaspartic acid and L-erythro- $\beta$-hydroxyaspartic acid by ${ }^{1} \mathrm{H}$ NMR spectra, in which these diastereoisomers were distinctly distinguishable, U-1 coincided with the threodiastereoisomer. Similarly, U-2 corresponded to D,L-threo- $\beta$-hydroxyleucine, but not to D,L-erythro$\beta$-hydroxyleucine. U-3 corresponded to D,L-threo- $\beta$-phenylserine, but not to $D, L$-erythro- $\beta$-phenylserine.

Measurement of $\mathrm{CD}$ of these amino acids indicated these to have L-configurations. Thus U-1 was identified with $L$-threo- $\beta$-hydroxyaspartic acid, U-2 with L-threo- $\beta$-hydroxyleucine and U-3 with L-threo- $\beta$-phenylserine.

$\mathrm{U}-1$ (HyAsp), CD: $[\theta]_{200}+5,320,[\theta]_{205}+6,970,[\theta]_{245} 0(c 0.0652,0.5 \mathrm{~N} \cdot \mathrm{HCl})$

U-2 (HyLeu), CD: $[\theta]_{200}+4,370,[\theta]_{205}+5,050,[\theta]_{245} 0(c 0.0579,0.5 \mathrm{~N} \mathrm{HCl})$

U-3 (PhSer), CD: $[\theta]_{205}+2,200,[\theta]_{216}+17,300,[\theta]_{250}+140(c 0.0503,0.5 \mathrm{~N} \mathrm{HCl})$

Stereochemistries of the Usual Amino Acid Residues

Some $100 \mathrm{mg}$ of a complex of 1 and 2 were hydrolyzed with constant boiling $\mathrm{HCl}$ at $110^{\circ} \mathrm{C}$ for 5 hours. The hydrolysate was subjected to preparative paper chromatography on a paper (Toyo Roshi No. 51) with PrOH - pyridine- AcOH - water $(15: 10: 3: 12)$. The zones of Rf ca. 0.47 which contained Ser, Gly and Arg, Rf ca. 0.60 which contained mainly Thr, and Rf $c a .0 .70$ which contained Val, Ile and Leu, were cut out and extracted with $50 \% \mathrm{MeOH}$. Each extract was concentrated and L-leucylated in the usual manner ${ }^{5)}$. The L-leucylated amino acid mixtures were compared 
by HPLC on Nucleocil $10 \mathrm{C}_{18}$ column $(4.6 \times 150 \mathrm{~mm})$ with acetonitrile $-50 \mathrm{~mm}$ phosphate buffer, pH 4.5 (the content of acetonitrile was varied to obtain appropriate retention time for each compound) with the following reference dipeptides: L-Leu-L-Ser, L-Leu-D-Ser, L-Leu-L-Arg, L-Leu-D-Arg, L-LeuL-Thr, L-Leu-D-Thr, L-Leu-L-aThr, L-Leu-D-aThr, L-Leu-L-Val, L-Leu-D-Val, L-Leu-L-Ile, L-Leu-D-Ile, L-Leu-L-Leu and L-Leu-D-Leu. Consequently, Ser was clarified to have L-configuration, Thr D-alloconfiguration, Val L-configuration, Ile L-configuration and Arg D-configuration, respectively, and the three Leu residues were one $\mathrm{D}$-form and two L-forms.

Alkali-treated Katanosin A (3)

Some $23 \mathrm{mg}$ of 1 was dissolved in a small amount of $\mathrm{MeOH}$ and diluted with $0.1 \mathrm{~N} \mathrm{NaOH}(10 \mathrm{ml})$. After standing at room temp for 10 minutes, the solution was extracted with $\mathrm{BuOH}(10 \mathrm{ml})$. The extract was water-washed, evaporated on adding water and finally freeze-dried to give a colorless powder $(17 \mathrm{mg})$. All the amino acid residues in 1 were found by hydrolysis and amino acid analysis. The IR spectrum is illustrated in Fig. 1.

\section{Reduction with Lithium Borohydride}

Some $2 \mathrm{mg}$ of 1 was dissolved in $\mathrm{MeOH}(2 \mathrm{ml})$, and lithium borohydride ( $2 \mathrm{mg}$ ) was added. The solution was allowed to stand at room temp for 20 hours. Then, the solution was diluted with dil $\mathrm{HCl}$, neutralized with $\mathrm{NaHCO}_{3}$ and extracted with $\mathrm{BuOH}$. The extract was concentrated to a residue, which was hydrolyzed and subjected to amino acid analysis. Compound $\mathbf{3}$ was also processed similarly. The results are shown below.

\begin{tabular}{cccccccccc}
\hline & \multicolumn{10}{c}{ Amino acid found (in ratio) } \\
\cline { 2 - 10 } & HyAsp $^{\mathrm{a}}$ & aThr $^{\mathrm{b}}$ & Ser & HyLeu $^{\mathrm{a}}$ & Gly & PhSer $^{\mathrm{a}}$ & Val & Leu & Arg \\
\hline $\mathbf{1}$ & 0.75 & 0.92 & 0.03 & 0.84 & 1.00 & 0.19 & 1.01 & 3.46 & 0.90 \\
$\mathbf{3}$ & 0.77 & 0.89 & 0.77 & 0.85 & 1.00 & 0.12 & 1.01 & 4.00 & 0.99 \\
\hline
\end{tabular}

a Calculation is based on Gly as a standard.

b Calculation is based on Thr as a standard.

\section{Chromic Acid Oxidation}

Chromic acid $(100 \mathrm{mg})$ was dissolved in a mixture of pyridine $(0.1 \mathrm{ml})$ and $\mathrm{AcOH}(3 \mathrm{ml})$, and a small residue was filtered off. Some $1 \mathrm{mg}$ of 1 was dissolved in the chromic acid solution $(0.1 \mathrm{ml})$ and allowed to stand for 20 hours at room temp. After addition of $\mathrm{MeOH}(1.5 \mathrm{ml})$, the reaction mixture was dried to a residue, which was hydrolyzed and analyzed with an amino acid analyzer. Compound 3 was also processed similarly.

\begin{tabular}{ccccccccccc}
\hline & \multicolumn{1}{c}{ Amino acid found (in ratio) } \\
\cline { 2 - 10 } & HyAsp $^{\mathrm{a}}$ & aThr $^{b}$ & Ser & HyLeu $^{a}$ & Gly & PhSer $^{\mathrm{a}}$ & Val & Leu & Arg \\
\hline $\mathbf{1}$ & 0.03 & 0 & 0 & 0 & 1.00 & 0.18 & 1.01 & 2.53 & 0.86 \\
$\mathbf{3}$ & 0.05 & 0 & 0 & 0 & 1.00 & 0 & 1.15 & 2.11 & 0.91 \\
\hline
\end{tabular}

a Calculation is based on Gly as a standard.

b Calculation is based on Thr as a standard.

\section{Edman Degradation on 3}

Some $2 \mathrm{mg}$ of 3 was subjected to Edman degradation. In this experiment, the separation of the PTC-amino acid and the residual peptide was carried out by partition between EtOAc and water layers, and identification of PTH-amino acid was based on TLC experiments. 


\begin{tabular}{|c|c|c|c|c|c|c|c|c|c|c|}
\hline & \multirow{2}{*}{$\begin{array}{l}\text { PTH- } \\
\text { Amino } \\
\text { acid }\end{array}$} & \multicolumn{9}{|c|}{ Amino acid found (in ratio) } \\
\hline & & HyAspa & $\mathrm{aThr}^{\mathrm{b}}$ & Ser & HyLeu $^{\mathrm{a}}$ & Gly & $\mathrm{PhSer}^{\mathrm{a}}$ & Val & Leu & Arg \\
\hline $\begin{array}{l}\text { Original } \\
\text { peptide }\end{array}$ & & 0.93 & 0.93 & 0.93 & 0.85 & 1.00 & 0.36 & 0.89 & 3.02 & 0.93 \\
\hline Step 1 & Leu & 0.82 & 0.91 & 0.89 & 0.82 & 1.00 & 0.30 & 0.93 & 2.00 & 0.92 \\
\hline Step 2 & Leu & 0.82 & 0.90 & 0.88 & 0.82 & 1.00 & 0.21 & 0.92 & 1.03 & 0.92 \\
\hline Step 3 & PhSer & 0.81 & 0.94 & 0.88 & 0.89 & 1.00 & 0.01 & 0.94 & 1.04 & 0.90 \\
\hline Step 4 & + & 0.78 & 0.89 & 0.88 & 0.06 & 1.00 & 0.02 & 0.92 & 1.02 & 0.98 \\
\hline Step 5 & Leu & 0.79 & 0.90 & 0.88 & 0.04 & 1.00 & 0.01 & 0.92 & 0.13 & 0.92 \\
\hline Step 6 & - & 0.76 & 0.87 & 0.86 & 0.04 & 1.00 & 0.02 & 0.87 & 0.12 & 0.12 \\
\hline Step 7 & Val & 0.77 & 0.86 & 0.86 & 0.03 & 1.00 & 0.02 & 0.14 & 0.07 & 0.10 \\
\hline Step 8 & $\begin{array}{l}\text { aThr }{ }^{\circ} \\
\Delta \mathrm{Thr}\end{array}$ & 0.78 & 0.21 & 0.88 & 0.03 & 1.00 & 0.01 & 0.13 & 0.06 & 0.08 \\
\hline Step 9 & Gly & 0.90 & 0.22 & 1.00 & 0.03 & 0.40 & 0.02 & 0.15 & 0.08 & 0.10 \\
\hline Step 10 & + & 0.36 & 0.21 & $1.00^{\mathrm{d}}$ & 0.03 & 0.34 & 0.00 & 0.14 & 0.06 & 0.09 \\
\hline
\end{tabular}

a Calculation is based on Gly as a standard.

b Calculation is based on Thr as a standard.

c PTH-Thr was used as a reference for the identification.

d When analyzed before hydrolysis, only Ser was detected.

+ : Not identified.

- : Not detected.

\section{Acknowledgments}

The authors wish to thank Professor TeTsuo SHIBA of Osaka University for supplying the samples of $\mathrm{L}$ threo- $\beta$-hydroxyaspartic acid, L-erythro- $\beta$-hydroxyaspartic acid, D,L-threo- $\beta$-hydroxyleucine, D,L-erythro- $\beta$ hydroxyleucine, $D, L$-threo- $\beta$-phenylserine and $D, L$-erythro- $\beta$-phenylserine.

\section{References}

1) Shour, J.; H. Hinoo, K. Matsumoto, T. Hattori, T. Yoshida, S. Matsuura \& E. Kondo: Isolation and characterization of katanosins A and B. J. Antibiotics 41: 713 718, 1988

2) Hunt, S.: The non-protein amino acids. In Chemistry and Biochemistry of the Amino Acids. Ed., G. C. BARReT, pp. 55 138, Chapman and Hall, London, 1985

3) Ishiyama, T.; T. Furuta, M. Takai, Y. Okimoto, S. Aizawa, A. Shimazu \& H. Yonehara: L-threo- $\beta$ Hydroxyaspartic acid as an antibiotic amino acid. J. Antibiotics 28:821 823, 1975

4) Dalby, S.; G. W. Kenner \& R. C. Sheppard: Peptides. Part X. B-Hydroxyleucine. J. Chem. Soc. 1960: $968 \sim 973,1960$

5) Mitchell, A. R.; S. B. H. Kent, I. C. Chu \& R. B. Merrifield: Quantitative determination of D- and L-amino acids by reaction with tert-butyloxycarbonyl-L-leucine $N$-hydroxysuccinimide esters and chromatographic separation as $\mathrm{L}, \mathrm{D}-$ and L,L-dipeptides. Anal. Chem. 50: 637 640, 1978 